\title{
Hydrological modeling using the SWAT model based on two types of data from the watershed of Beni Haroun dam, Algeria
}

\author{
Zakaria KATEB $^{1) \text { ABCDEF }}$, Hamid BOUCHELKIA ${ }^{2) ~ A C D E ~} \bowtie$, \\ Abdelhalim BENMANSOUR ${ }^{1) \text { ADE }}$, Fadila BELARBI ${ }^{1)}$ ADE
}

\author{
1) University of Tlemcen, Department of Hydraulic, URMER Laboratory, Tlemcen, Algeria; e-mail: zakari_1231@hotmail.fr; \\ halim_benmansour@yahoo.fr; fabelarbi@yahoo.fr \\ 2) orcid.org/0000-0002-0633-0655; University of Tlemcen, Department of Hydraulic, URMER Laboratory, BP, 13000, Tlemcen, \\ Algeria; e-mail: h_bouchelkia@yahoo.fr
}

For citation: Kateb Z., Bouchelkia H., Benmansour A., Belarbi F. 2019. Hydrological modelling using the SWAT model based on two types of data from the watershed of Beni Haroun dam, Algeria. Journal of Water and Land Development. No. 43 (X-XII) p. 76-89. DOI: 10.2478/jwld-2019-0065.

\begin{abstract}
The dam of Beni Haroun is the largest in Algeria, and its transfer structures feed seven provinces (wilayas) in the eastern part of Algeria. Due to its importance in the region, it has now become urgent to study its watershed as well as all the parameters that can influence the water and solid intakes that come into the dam. The Soil and Water Assessment Tool (SWAT) model is used to quantify the water yields and identify the vulnerable spots using two scenarios. The first one uses worldwide data (GlobCover and HWSD), and the second one employs remote sensing and digital soil mapping in order to determine the most suitable data to obtain the best results. The SWAT model can be used to reproduce the hydrological cycle within the watershed. Concerning the first scenario, during the calibration period, $R^{2}$ was found between 0.45 and 0.69 , and the Nash-Sutcliffe efficiency (NSE) coefficient was within the interval from 0.63 to 0.80 ; in the validation period, $R^{2}$ lied between 0.47 and 0.59 , and the NSE coefficient ranged from 0.58 to 0.64 . As for the second scenario, during the calibration period, $R^{2}$ was between 0.60 and 0.66 , and the NSE coefficient was between 0.55 and 0.75 ; however, during the validation period, $R^{2}$ was in the interval from 0.56 to 0.70 , and the NSE coefficient within the range $0.64-0.70$. These findings indicate that the data obtained using remote sensing and digital soil mapping provide a better representation of the watershed and give a better hydrological modelling.
\end{abstract}

Key words: Beni Haroun, calibration, SWAT model, water yields, watershed

\section{INTRODUCTION}

Based on his work, Xavier Leflaive indicated that water demands and needs are going to increase by $55 \%$, between the years 2000 and 2050 . This increase will essentially come from various water uses, such as drinking water, irrigation water, manufacturing water, domestic water, etc. [LEFLAIVE 2012]. Therefore, conserving, planning, developing, distributing and managing efficiently the optimum use of water resources represent the best guarantee for equitable access to potable water and sanitation as a fundamental right.
Consequently, in order to remedy the water shortage problem, it is urgently required to know and better understand the whole process in the relationship between the water cycle and the watershed. Moreover, studying, planning, managing and building water catchment areas and water storage structures are deeply needed for the collection and preservation of runoff water [ARMON, HÄNNINEN 2016].

Nowadays, siltation of water reservoirs is seen as one of the most serious technical problems; it is mainly caused by water erosion. The siltation process has a negative im- 
pacts on the economy, ecology and all surface water resources [SCHMIDT 2013].

Algeria is one of the countries threatened by the problem of water resource scarcity. Indeed, the Intergovernmental Panel on Climate Change [IPCC] indicated that water availability will drop significantly (between 10 and $40 \%$ ) during the period extending from 2090 to 2100 [BATES et al. 2009].

In order to predict erosion, it is essential to study all the parameters that have a direct impact on this process for the purpose of building appropriate dams and manage them adequately. Due to the importance and severity of this process in virtually all Algerian watersheds. Applying different water erosion simulation models in watersheds allows researchers to estimate the water and sedimentation yields and to predict vulnerable points within the watershed [DE VENTE, POESEN 2005].

Various hydrological models may be applied to understand, estimate, evaluate and even control natural and human activities in watersheds [ZHANG et al. 2012], such as European Soil Erosion Model (EUROSEM), Groundwater Loading Effects of Agricultural Management Systems (GLEAMS), Limburg Soil Erosion Model (LISEM), Griffith University Erosion System Template (GUEST), and Water and Tillage Erosion Model (WATEM) [BLANCO-CANQUI, LAL 2010] and the Soil and Water Assessment Tools model (SWAT) [ARNOLD et al. 1998].

The SWAT model is a continuous hydrologic model; it is a fully distributed, physics-based rainfall-runoff model that runs on a daily time step with a GIS interface [ARNOLD et al. 1998; 2013; NEITSCH et al. 2011]. Over the last few years, this model has been used throughout the entire world. Moreover, it has attracted considerable attention from many researchers due to its effectiveness and feasibility in different types of watersheds. The model may be applied in a wide range of options; it can be employed in assessing and estimating hydrological parameters. In addition, this model can be used in investigating the impact of climate change, as well as identifying different sources of pollution, monitoring crop growth and managing land practices in watersheds; this model can be run at multiple time steps including daily, monthly, and yearly [DOUGLAS-MANKIN et al. 2010; GASSMAN et al. 2014; TUPPAD et al. 2011].

The dam of Beni Haroun along with its transfer systems represent one of the many mega projects that have been realized in Algeria so far. According to the National Agency for Dams and Transfers (Fr. Agence Nationale des Barrages et Transferts - ANBT), this dam is supposed to feed seven Provinces (wilayas), namely Jijel, Mila, Constantine, Oum el Bouaghi, Khenchla, Batna, and Biskra; it is also expected to provide the irrigation of 40000 hectares of land [SOUKEHAL, CHERRAD 2011].

It is therefore essential today to carry out studies on the watershed characteristics and to investigate the entire hydrological cycle using the SWAT model with appropriate input data. The results obtained can be employed to estimate and predict the areas at risk, facilitate water resources management, protect important streams, ensure incoming water flows into the dam, protect urban areas exposed to flooding risk and extend the average life expectancy of a dam. The model needs a lot of input data that are not easy to get and are hard to find in Algeria. The ones available are incomplete; they do not allow conducting a successful simulation study. To solve this problem, we use global data [GIRI 2012]. Furthermore, create our database using remote sensing of satellite images that contains the information necessary for the land use data, and for soil types using digital soil mapping.

The present study aims primarily to:

- create a database using the geographic information system (GIS) and remote sensing; the results from the analyses of the samples collected may be used as input data in the model;

- apply the SWAT model to conduct simulations while using worldwide data as well as information obtained from remote sensing and digital soil mapping; note that the model needs to be calibrated first, using the database provided by the hydrometric station;

- compare the simulation results with the data from the water flow control stations;

- determine which data type gives the best results.

\section{STUDY AREA AND STUDY METHODS}

\section{DESCRIPTION OF THE STUDY AREA}

The watershed of Beni Haroun dam is located in the northeast Algeria in the large watershed Kebir-Rhumel (Fig. 1), it covers an area of $639,464.56$ ha $\left(6,394.64 \mathrm{~km}^{2}\right)$ with a variant altitude of 42 to $1,719 \mathrm{~m}$, and it is located between $5.42153981 \mathrm{E}, 35.85967386 \mathrm{~N}$ and $7.02042307 \mathrm{E}$, $36.60946372 \mathrm{~N}$. The average annual rainfall is $610 \mathrm{~mm}$ and the average annual temperature is $18^{\circ} \mathrm{C}$, the basin is within two bioclimatic classes, being semi-arid in the South and sub humid in the North [ANRH 2005c]. The major streams in the watershed are wadi Bou Merzoug, Rhumel, Kebir, Endja [ANRH 2005b], the average annual precipitation of the watershed is between 500 and 1,400 mm [ANRH 2008].

The Beni Haroun dam watershed is mainly divided into two large sub-basin, the watershed of the Rhumel stream in the East, which is located in 2 biochemical classes semiarid in the southern part and sub-humid in the northern part. In addition, the watershed of the Kebir stream in the West, which is sub-humid.

The watershed is controlled by several hydrometric and climatic stations, in this study three hydrometric stations are used for comparison, its main purpose is to measure water and sediment yields.

1. The Grarem station, which controls $4,039 \mathrm{~km}^{2}$ in the northeastern part of the watershed that measures water and sediment yields, which will arrive at the dam from of the Rhumel sub-basin.

2. Ain Smara station, which controls $1,101 \mathrm{~km}^{2}$ in the southern part of the basin in the Wadi Athmania part of the Rhumel watershed.

3. The Tassadane station which controls $914.7 \mathrm{~km}^{2}$ in the North-West part in the Kebir sub-basin. 


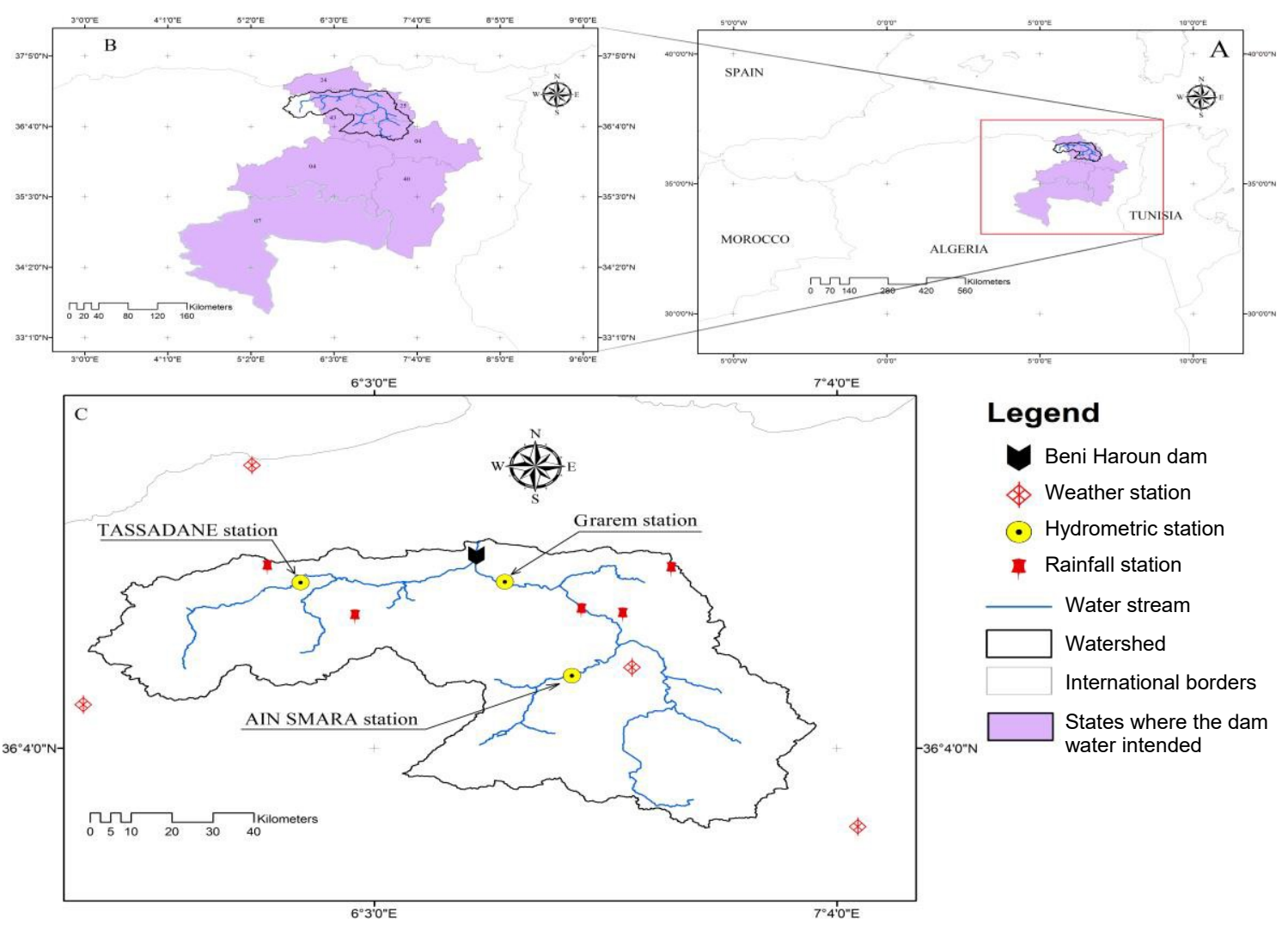

Fig. 1. Study area location: A) location of the Beni Haroun basin in Algeria; B) location of the dam with the willaya benefiting from its waters; C) Location and distribution of hydrological and meteorological stations; source: own elaboration

For rainfall, climatic data there are several stations in the watershed. The Algerian National Office of Meteorology (Fr. Office National de Météorologie - ONM) provides the meteorological stations, and the National Water Resources Agency (Fr. Agence Nationale des Ressources Hydrique - ANRH) provides the rainfall station. In this study uses four climatic station and five rainfall stations.

The importance of the dam is raised by the drinking water supply for 6 million inhabitants of seven different willayas who benefited from the water of the dam, and in the near future the irrigation of 40,000 ha [SOUKEHAL, CherRad 2011].

\section{PRESENTATION OF THE SOIL AND WATER ASSESSMENT TOOL (SWAT) MODEL}

SWAT is a physical model on a continuous basis that uses the daily time step at the scale of the watersheds. Developed by the USDA (United States Department of Agriculture) to estimate and predict the influence of different hydrological parameters such as land use cover, soil types and climatic parameters on water, sedimentation, pollution, nutrient transfer, crop growth, the environment and climate change in watersheds [ARNOLD et al. 1998; 2013; NEITSCH et al. 2011 ].

The hydrological cycle is simulated by the model on the basis of the following equilibrium equation of water:

$S W_{t}=S W_{0}+\sum_{1=1}^{t}\left(R_{\text {day }}-Q_{\text {surf }}-E_{a}-W_{\text {seep }}-Q_{\mathrm{gw}}\right)(1)$
Where: $t=$ time (days), $S W t=$ final soil moisture content $(\mathrm{mm}) ; S W_{0}=$ initial water content of the soil $(\mathrm{mm}) ; R_{\text {day }}=$ amount of precipitation at day $i(\mathrm{~mm}) ; Q_{\text {surf }}=$ quantity of runoff water at day $i(\mathrm{~mm}) ; E_{a}=$ amount of evapotranspiration at day $i(\mathrm{~mm}) ; w_{\text {seep }}=$ quantity of water entering the unsaturated zone of the soil profile on day $i(\mathrm{~mm}) ; Q_{\mathrm{gw}}=$ the amount of the return flow on day $i(\mathrm{~mm})$.

$$
q_{\text {peak }}=\frac{\alpha q A}{360 t_{c}}
$$

Where: $q_{\text {peak }}=$ peak runoff rate $\left(\mathrm{m}^{3} \cdot \mathrm{s}^{-1}\right) ; q=$ the runoff (mm); $A=$ hydrological response unit (HRU) area (ha); $t_{c}=$ the concentration time (h); $\alpha=$ dimensionless parameter that expresses the proportion of total precipitation that occurs during $t_{c}$.

\section{DATA TYPES}

The SWAT model has several interfaces like ARCSWAT version 2012, which is used to enter the different types of data needed to make a simulation in the model.

In addition to the data as the digital elevation model, the land use and soil types, the model requires other types of data such as metrological data. The model divides the watershed into sub-watershed and those into hydrological response units (HRU's)generate by slope classes, soil type classes and land cover [ARNOLD et al. 1998; 2013; NeITSCH et al. 2011 ]. 


\section{THE DIGITAL ELEVATION MODEL (DEM)}

DEM used in SWAT model, obtained from ASTER Global Digital Elevation V2 Model with a resolution of 28 $\mathrm{m}$, to delimit the watershed and cuts sub-basin, delimit the location of watercourses and create the slopes classes map. Sub-basin cutting was done taking into consideration the location of the hydrometric stations and the automatic cutting (Fig. 2A).

\section{LAND USE}

Two types of data used in this study: GlobCover and the maps extracted from remote sensing of LANDSAT 8 satellite imagery.

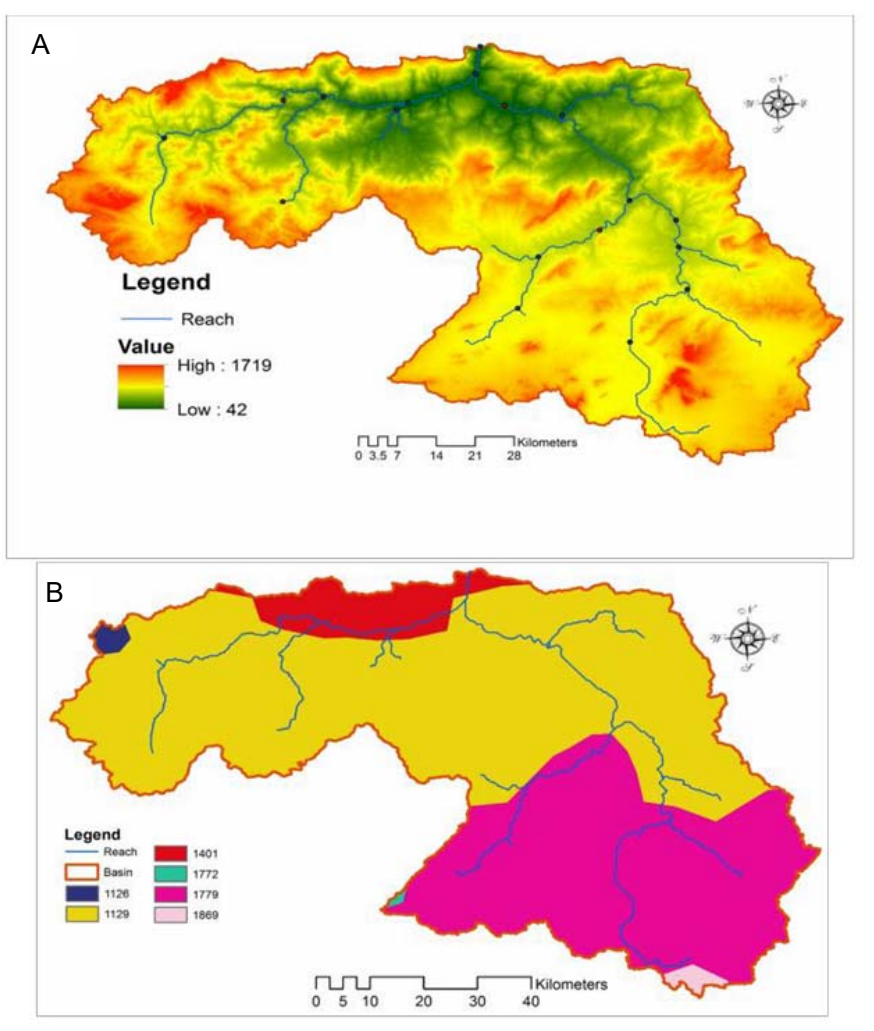

\section{- GlobCover}

Created by the European Space Agency, the class types of this database are different from the SWAT classes that use the Anderson classification [ANDERSON 1976; GIRI 2012]. Anderson has developed a multi-level class system for land use. To adapt this database to the model, we convert these classes into the Anderson classification level 01 and follow level 02 .

EL-SADEK and IRVEM [2014] show the GlobCover class distribution in relation to the Anderson level 01 classification and the Anderson level 2 classification transformation (Fig. 2C, Tab. 1).

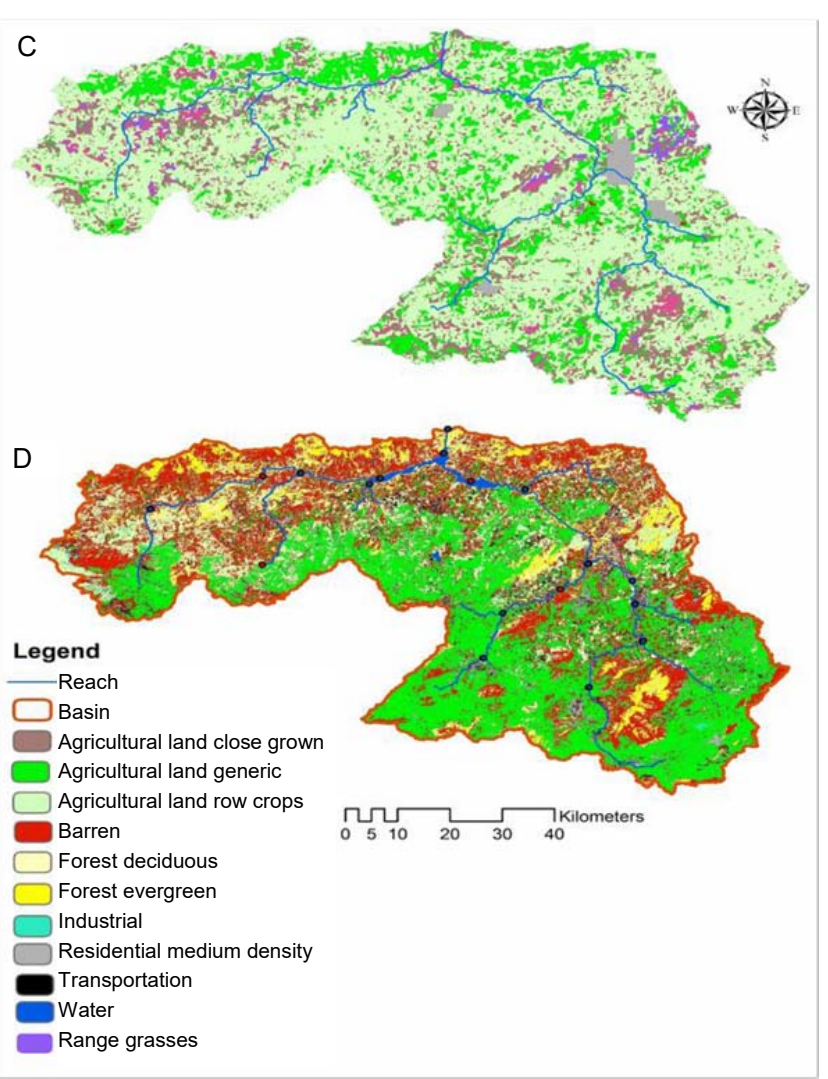

Fig. 2. Data types: A) digital elevation model of the Beni Haroun dam watershed, B) GlobCover land use map, C) land use map using remote sensing, D) HWSD soil type map; source: own study

Table 1. Land use class by Anderson level 1, 2 and GlobCover classes and the SWAT code of each class [CONGALTON et al. 2014]

\begin{tabular}{|c|c|c|c|}
\hline Anderson classes level 1 & Description of GlobCover classification & Anderson classes level 2 & $\begin{array}{c}\text { SWAT } \\
\text { code }\end{array}$ \\
\hline Urban or built-up land & artificial surfaces and associated areas (urban areas $>50 \%$ ) & residential - medium density & URMD \\
\hline \multirow{3}{*}{ Agricultural land } & rainfed crops & agricultural land generic & AGRL \\
\hline & mosaic cropland (50-70\%) / vegetation (grassland/shrubland/forest) $(20-50 \%)$ & agricultural land row crop & AGRR \\
\hline & mosaic vegetation (grassland/shrubland/forest) $(50-70 \%) /$ cropland $(20-50 \%)$ & agricultural land close grown & AGRC \\
\hline Rangeland & mosaic grassland $(50-70 \%)$ / forest or shrubland $(20-50 \%)$ & range grasses & RNGE \\
\hline \multirow{3}{*}{ Forest } & closed $(>40 \%)$ broadleaved deciduous forest $(>5 \mathrm{~m})$ & forest deciduous & FRSD \\
\hline & mosaic forest or shrubland $(50-70 \%)$ / grassland $(20-50 \%)$ & forest mixed & FRST \\
\hline & closed $(>40 \%)$ needle leaved evergreen forest $(>5 \mathrm{~m})$ & forest evergreen & FRSE \\
\hline Barren land & bare areas & barren & BARR \\
\hline Water & water bodies & water & WATR \\
\hline
\end{tabular}

Source: own elaboration based on GlobCover database. 
- Using remote sensing of LANDSAT 8 satellite imagery

LANDSAT 8 satellite imagery was imported from the USGS database. Using supervised classification [BOETTINGER et al. 2008] by ERDAS software [Geosystems 2005], and the manipulation by the ARCGIS software of the spectral band of the LANDSAT 8 ETM satellite image + https://glovis.usgs.gov/ The newest satellite in the Landsat series offers scientists a clearer view with better spatial resolution. providing moderate spatial resolution, global, synoptic, and repetitive coverage of the Earth's land surfaces [ACHARYA, YANG 2015; BARSI et al. 2014; BOETTINGER et al. 2008; PARECE et al. 2014] in order to identify all types of land use classes using Anderson's classification [ANDERSON 1976]. The map correction was made using World Imagery data. (Fig. 2C, Tab. 2) shows the surface percentages of each class of land use.

Table 2. Percentage of area of each land use classes in the watershed of Beni Haroun dam

\begin{tabular}{|l|r|r|c|}
\hline \multicolumn{1}{|c|}{ Class } & Area (ha) & Percentage & $\begin{array}{c}\text { SWAT } \\
\text { code }\end{array}$ \\
\hline Industrial & 952.20 & 0.15 & UIDU \\
\hline Transportation & 29390.25 & 4.65 & UTRN \\
\hline Water & 3968.29 & 0.63 & WATR \\
\hline Forest - evergreen & 35383.38 & 5.60 & FRSE \\
\hline Forest - deciduous & 11835.68 & 1.87 & FRSD \\
\hline Barren & 180348.62 & 28.53 & BARR \\
\hline Agricultural land - generic & 233668.60 & 36.96 & AGRL \\
\hline Agricultural land - close-grown & 2702.17 & 0.43 & AGRC \\
\hline Residential - medium density & 17261.76 & 2.73 & URMD \\
\hline Agricultural land - row crops & 116697.31 & 18.46 & AGRR \\
\hline
\end{tabular}

Source: own study.

\section{SOIL TYPES}

Two types of data used in this study: the first, Harmonized World Soil Data base map and database (HWSD). For the second we create our map and database based on remote sensing of satellite images and digital soil mapping.

1. Harmonized World Soil Database map and database - HWSD

The HWSD database is created by FAO and IIASA in the aim of developing regional databases and global soil information [NACHTERGAELE et al. 2008] (Fig. 2D, Tab. $3)$. The attribute tables of the SWAT soft-ware do not contain this database for that we must modify them by integrating them in these tables, some of the necessary parameters for a simulation [ARNOLD et al. 2013; NEITSCH et

Table 3. The Harmonized World Soil Database (HWSD) soil classes

\begin{tabular}{|c|c|r|r|c|}
\hline Class & $\begin{array}{c}\text { Erodibility } \\
\text { factor } K\end{array}$ & Area (ha) & Percentage & $\begin{array}{c}\text { USDA texture } \\
\text { classification }\end{array}$ \\
\cline { 1 - 4 } 1126 & 0.177 & 3290.83 & 0.51 & \multirow{2}{*}{ loam } \\
\cline { 1 - 4 } 1129 & 0.177 & 375174.78 & 58.67 & \\
\cline { 1 - 4 } 1401 & 0.180 & 38230.42 & 5.98 & \\
\hline 1772 & 0.176 & 695.07 & 0.11 & \\
\cline { 1 - 4 } 1779 & 0.173 & 218054.90 & 34.10 & clay \\
\hline 1869 & 0.161 & 4018.55 & 0.63 & \\
\hline
\end{tabular}

Source: Harmonized World Soil Database. al. 2011] does not exist in the HWSD database but can calculate it independently as:

- the capacity of the available soil water $\left(\mathrm{mm} \mathrm{H}_{2} \mathrm{O}\right.$ per $\mathrm{mm}$ of soil) and the saturated hydraulic conductivity $(\mathrm{mm}$ per $\mathrm{h})$ are determined using a program called SPAW [SAXTON, RAWLS 2006) soil plant atmosphere water;

- the erodibility factor $K$ of the universal soil loss equation (USLE) formula with the Williams formula [WILLIAMS 1995]

$$
K_{\mathrm{USLE}}=f_{c \text { sand }} \cdot f_{c l-s i} \cdot f_{\text {org }} \cdot f_{\text {hisand }}
$$

Where: $f_{\text {csand }}=$ a factor that gives low soil erodibility factors for soils with high coarse-sand contents and high values for soils with little sand; $f_{c l-s i}=\mathrm{a}$ factor that gives low soil erodibility factors for soils with high clay to silt ratios; $f_{\text {org }}=\mathrm{a}$ factor that reduces soil erodibility for soils with high organic carbon content; $f_{\text {hisand }}=$ a factor that reduces soil erodibility for soils with extremely high sand contents.

\section{Creating our database map of soil types based on} remote sensing and digital soils mapping

To achieve this goal we follow four steps as shown in Fig. 3A.

- Choice of the software tools and type of satellite images There is a several database of satellite images such as LANDSAT, ASTER, MODIS, AVHRR, HYPERION [HARTEMINK et al. 2008]. In our study, we use LANDSAT $8 \mathrm{ETM}+$ because it is a free, simple and easy database for downloading and manipulating, and there is a lot of research that uses these images in different domain such as [MWANIKI et al. 2015; RAKSHIT et al. 2017]. Moreover, for the software tool we use the ERDAS Imagine since this software is useful for extracting information from multispectral satellite images. Using the unsupervised method, which based on the automatic division of the software HARTEMINK et al. 2008], to spatialize homogeneous zones of soil type's (Fig. 3B).

- Processing satellite images and selecting the sampling sites

Based on the work of BOETTINGER et al. [2008], PARECE et al. [2014], and ACHARYA and YANG [2015] spectral bands 7-6-8 of the LANDSAT 8 satellite images are used to create a map of false colours to identify homogeneous zones of soil types Figure 3B. After dividing the satellite image into homogeneous areas by colour, we separate each class and convert it to a KMZ file in google earth to find out where each one is, and the type of land cover of each class in order to properly select the location of the samples.

The most used approaches in soil sampling campaigns are targeted sampling, systematic random sampling and simple random sampling [CARTER, GREGORICH 2008; Ministère... 2010]; each approach has its characteristics. Targeted sampling involves taking soil samples at a specific location; targeted sampling requires sufficient preliminary data on soils. In our case, when taking the homogeneous areas of satellite image and all the obstacles such as the size of the surface of the study area, the inaccessible and dangerous places and the topography of the study area 

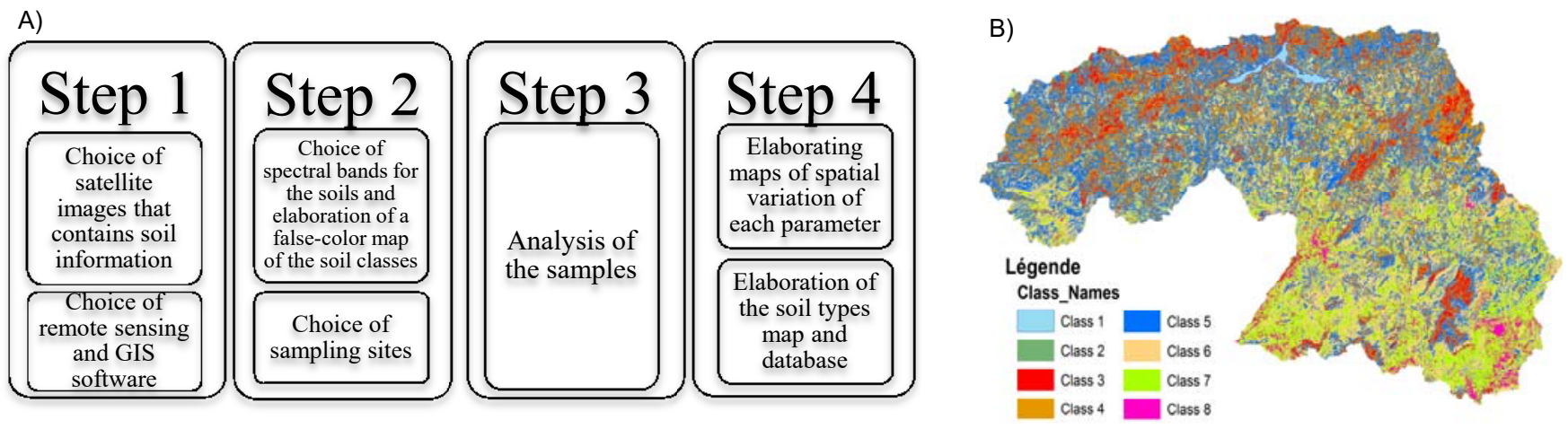

C)

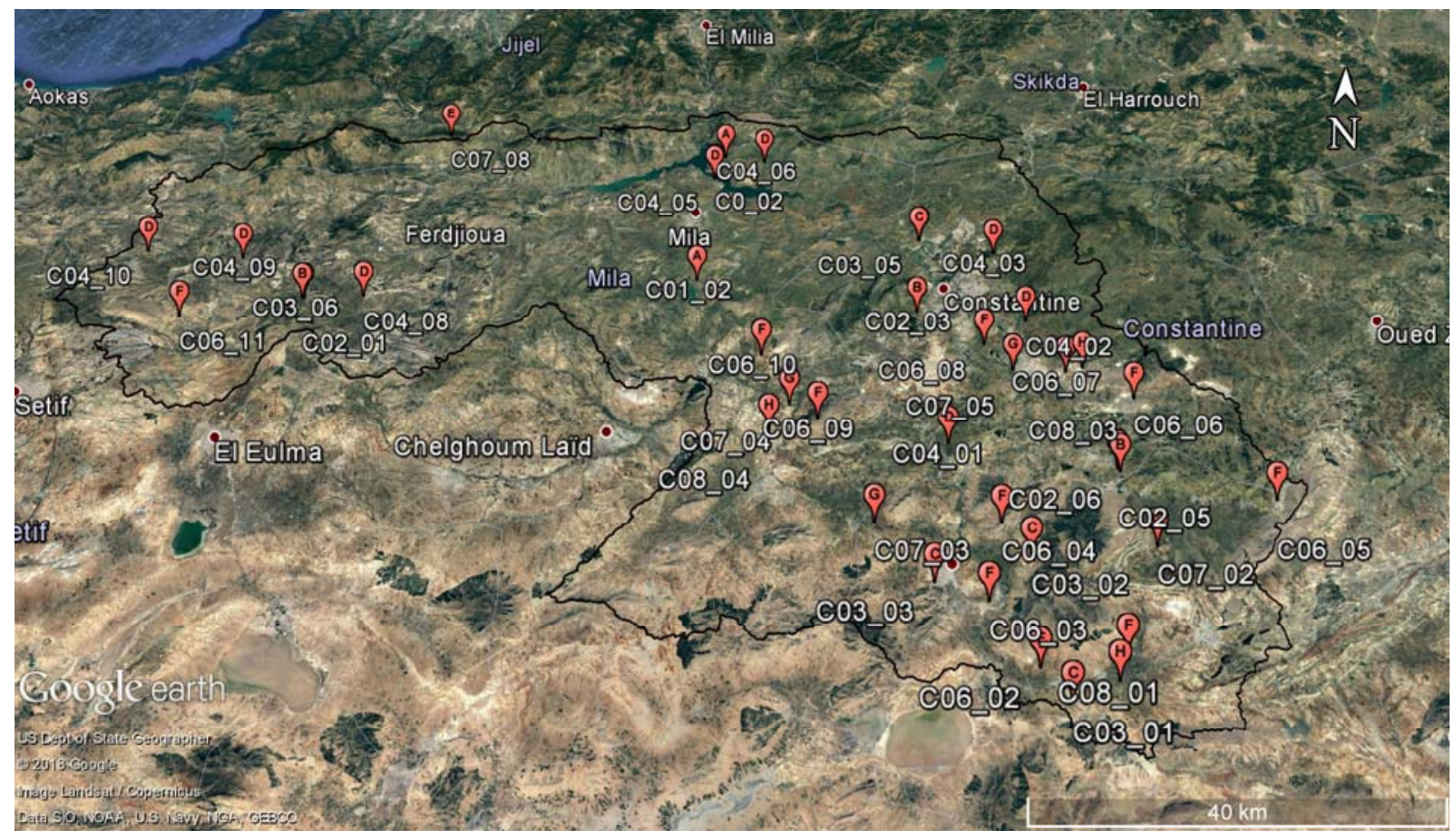

D)
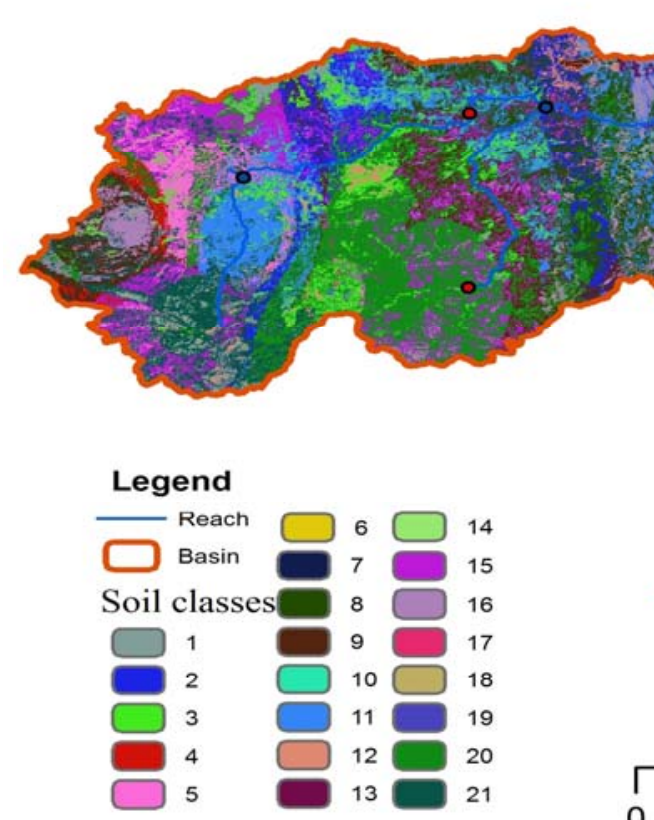
into consideration, the most convenient type of sampling is the simple random sampling. Taking into account the maps of land use classes, we chose the sites in Figure 3C.

\section{- Sample analysis}

The analyses of the samples on the 11 parameters necessary to make a simulation in the SWAT model [ARNOLD et al. 2013; NEITSCH et al. 2011] the percentage of: clay, silt, sand, gravel using the standards [AUBERT 1978; LCPC 1987; NFP 1996]. The apparent density, the humidity in the fields, hydraulic conductivity or permeability, $\mathrm{pH}$, electrical conductivity, total organic matter [AUBERT 1978] and we calculate the erodibility factor $K$ with the Williams formula [WiLliams 1995]. The data is shown in Table 4.

- Elaboration of the soil types map and database

After creating maps of 11 parameters based on the results of the analyses of the samples, we do the superposition of these maps to create the map of soil types and the database generated by the parameters necessary to make a SWAT model simulation (Fig. 3D, Tab. 4).

\section{HYDROMETRIC AND METROLOGICAL DATA}

The daily climate data of 4 meteorological stations are provided by the Algerian National Office of Meteorology (ONM), and 5 rainfall stations and 3 hydrometric stations to control the water and sediment yields in the watershed provided by the National Water Resources Agency [ANRH 2004] - Figure 1.

The model also requires a monthly weather database file in the weather database attribute table. For this we use the WGNmaker 4.1 software, a statistical program that calculates monthly weather averages based on daily data [SERGIO 2012] to fill the gaps of weather stations.

\section{MODEL CONFIGURATION}

To achieve the objectives of this study we divided our work into 4 steps which has 2 scenarios (Fig. 4).

The $1^{\text {st }}$, determine the data types for each scenario and modify and adjust these for the model.

The $2^{\text {nd }}$ is to do the simulation for each scenario and to see the preliminary results which helps to select and chose the necessary parameters for the calibration of the model.

The $3^{\text {rd }}$ comparative of the model calibration results with the data observe hydrometric gauging stations and validation.

The fourth is the comparison between the scenarios to see which one give us the best result.

\section{Scenario 1}

In this scenario, we use the following data:

1 - land use: GlobCover,

2 -soils types: Harmonized World Soil Data base (HWSD).

The model divided the basin into 31 sub-basin and consequently 1,010 HRU's.

\section{Scenario 2}

In this scenario, we use the following data:

1 - land use: using remote sensing data,

2 - soils types: using database of soil types based on remote sensing and digital mapping of soils.

The model divided the basin into 31 sub-basin as the first scenario for comparing the results and consequently 12,435 HRU's.

Table 4. The soil database

\begin{tabular}{|c|c|c|c|c|c|c|c|c|c|c|c|c|c|}
\hline $\begin{array}{l}\text { Soil } \\
\text { class }\end{array}$ & Clay & Silt & Sand & Gravel & $H C$ & $\mathrm{MO}$ & $K_{\text {USLE }}$ & $D$ & $E C$ & $A W C$ & Surface & $\begin{array}{l}\text { GRP } \\
\text { HYD }\end{array}$ & Texture \\
\hline 1 & 3.46 & 3.74 & 92.80 & 24.30 & 66.258 & 1.320 & 0.1768 & 1.69 & 144 & 10.84 & 546.89 & B & sand \\
\hline 2 & 5.57 & 1.62 & 92.80 & 24.30 & 150.617 & 4.917 & 0.1007 & 1.64 & 144 & 10.84 & 165.00 & B & sand \\
\hline 3 & 2.43 & 4.77 & 92.80 & 24.30 & 286.270 & 1.939 & 0.1584 & 1.64 & 216 & 15.66 & 128.68 & A & sand \\
\hline 4 & 4.62 & 2.43 & 92.95 & 24.42 & 150.617 & 1.939 & 0.1385 & 1.64 & 144 & 18.81 & 170.295 & $\mathrm{~B}$ & sand \\
\hline 5 & 7.33 & 5.29 & 87.38 & 24.82 & 416.470 & 3.078 & 0.1214 & 1.64 & 144 & 23.47 & 241.11 & $\mathrm{~A}$ & loamy sand \\
\hline 6 & 5.83 & 7.10 & 87.06 & 24.55 & 66.258 & 1.939 & 0.1584 & 1.69 & 144 & 10.84 & 119.48 & B & loamy sand \\
\hline 7 & 6.71 & 2.24 & 91.05 & 17.84 & 66.258 & 3.947 & 0.1584 & 1.64 & 144 & 10.84 & 190.18 & B & sand \\
\hline 8 & 4.62 & 2.43 & 92.95 & 24.42 & 150.617 & 3.947 & 0.1214 & 1.64 & 144 & 10.84 & 206.62 & B & sand \\
\hline 9 & 4.62 & 2.43 & 92.95 & 24.42 & 286.270 & 3.947 & 0.1385 & 1.64 & 216 & 15.66 & 166.50 & $\mathrm{~A}$ & sand \\
\hline 10 & 4.62 & 2.43 & 92.95 & 24.42 & 150.617 & 3.947 & 0.1214 & 1.64 & 144 & 23.47 & 98.21 & B & sand \\
\hline 11 & 2.77 & 8.28 & 88.95 & 33.49 & 66.258 & 3.078 & 0.1214 & 1.64 & 144 & 18.81 & 959.03 & B & sand \\
\hline 12 & 4.25 & 4.85 & 90.90 & 17.92 & 150.617 & 3.078 & 0.1768 & 1.64 & 144 & 23.47 & 329.01 & B & sand \\
\hline 13 & 4.62 & 2.43 & 92.95 & 24.42 & 286.270 & 3.078 & 0.1768 & 1.64 & 144 & 18.81 & 213.75 & $\mathrm{~A}$ & sand \\
\hline 15 & 4.25 & 4.85 & 90.90 & 17.92 & 66.258 & 3.947 & 0.1214 & 1.69 & 428 & 15.66 & 300.71 & B & sand \\
\hline 16 & 5.57 & 1.62 & 92.80 & 24.30 & 66.258 & 3.078 & 0.1385 & 1.64 & 144 & 18.81 & 829.17 & B & sand \\
\hline 17 & 6.62 & 2.24 & 91.14 & 17.92 & 150.617 & 1.320 & 0.1584 & 1.64 & 144 & 10.84 & 220.64 & $\mathrm{~B}$ & sand \\
\hline 18 & 6.62 & 2.24 & 91.14 & 17.92 & 150.617 & 6.122 & 0.1007 & 1.64 & 144 & 18.81 & 106.80 & $\mathrm{~B}$ & sand \\
\hline 19 & 6.62 & 2.24 & 91.14 & 17.92 & 150.617 & 6.940 & 0.0815 & 1.64 & 144 & 18.81 & 125.49 & $\mathrm{~B}$ & sand \\
\hline 20 & 6.62 & 2.24 & 91.14 & 17.92 & 66.258 & 3.078 & 0.1214 & 1.69 & 144 & 15.66 & 483.49 & B & sand \\
\hline 21 & 6.62 & 2.24 & 91.14 & 17.92 & 66.258 & 4.917 & 0.1214 & 1.64 & 144 & 7.70 & 656.02 & B & sand \\
\hline
\end{tabular}

Explanations: $H C=$ hydraulic conductivity; $\mathrm{MO}=$ organic matter; $K_{\mathrm{USLE}}=$ the erodibility factor $K$ of the universal soil loss equation; $D=$ density; $E C=$ electric conductivity; $A W C$ = available water capacity; GRP HYD = hydrological group.

Source: own study. 


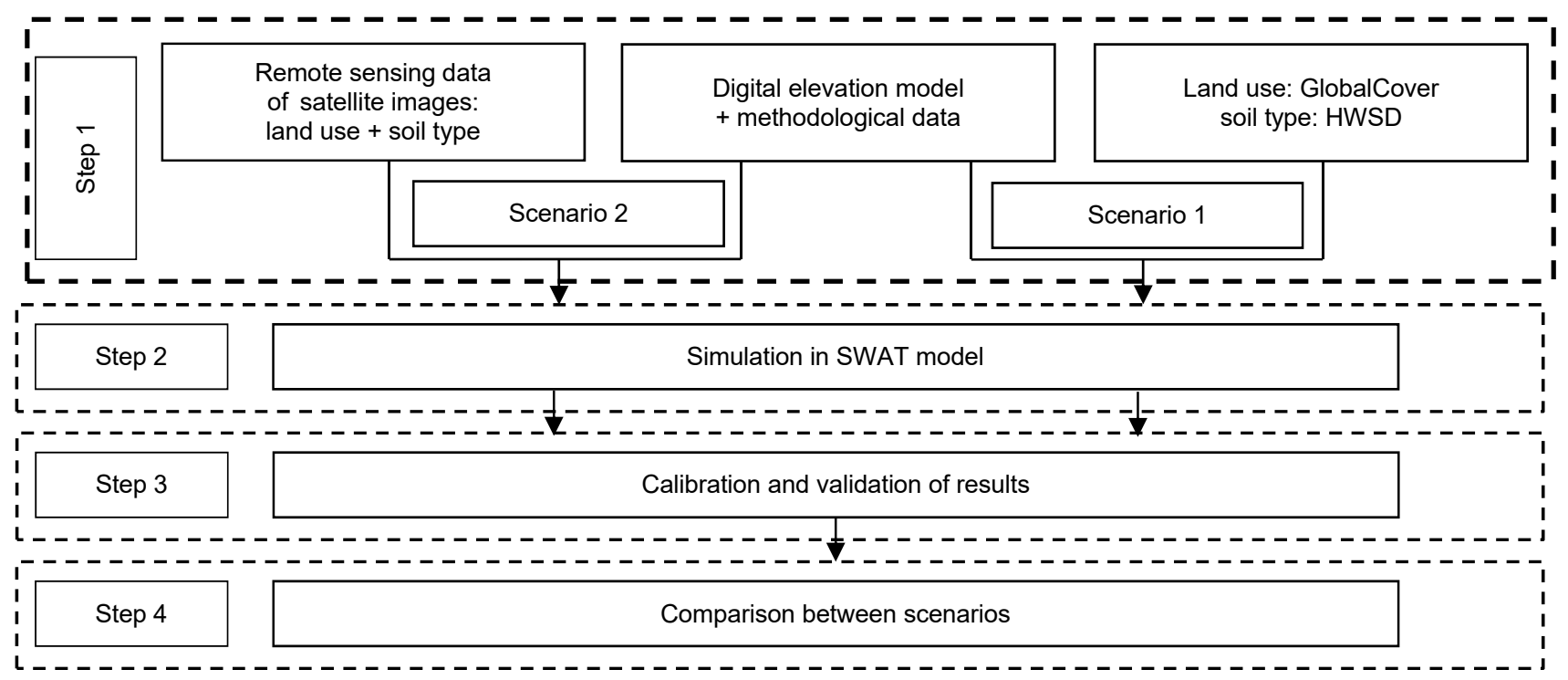

Fig. 4. The steps of work plan; source: own study

\section{RESULTS}

\section{PRELIMINARY RESULTS}

After the simulation of the daily time steps for both scenarios, we compare the results with data from gauging stations in the watershed. For scenario 1 (Fig. 5A1, B1, C1) and for scenario 2 (Fig. 5A2, B2, C2) using the following stations: Grarem station over the period 1992-2000 (Fig. 5A1/2), Ain Smara station over the period 1985-1991 (Fig. 5C1/2), Tassadane station over the period 1981-2006 (Fig. 5B1/2).

According to the preliminary results, our model requires a calibration for both scenarios:

- for the first scenario, the results show that the simulated discharge is bigger than the observed for the Grarem station (Fig. 5A1) - avg observed $=5.33 \mathrm{~m}^{3} \cdot \mathrm{s}^{-1}$, avg simulated $=14.47 \mathrm{~m}^{3} \cdot \mathrm{s}^{-1}$, max observed $=207.33 \mathrm{~m}^{3} \cdot \mathrm{s}^{-1}$, max simulated $=1118 \mathrm{~m}^{3} \cdot \mathrm{s}^{-1}$, Tassadane (Fig. 5B1) avg observed $=3.28 \mathrm{~m}^{3} \cdot \mathrm{s}^{-1}$, avg simulated $=3.14 \mathrm{~m}^{3} \cdot \mathrm{s}^{-1}$, max observed $=250.71 \mathrm{~m}^{3} \cdot \mathrm{s}^{-1}$, max simulated $=401.30$ $\mathrm{m}^{3} \cdot \mathrm{s}^{-1}$, except Ain Smara station (Fig. 5C1) - avg observed $=1.24 \mathrm{~m}^{3} \cdot \mathrm{s}^{-1}$, avg simulated $=0.47 \mathrm{~m}^{3} \cdot \mathrm{s}^{-1}, \max$ observed $=143.03 \mathrm{~m}^{3} \cdot \mathrm{s}^{-1}$, max simulated $=142.70 \mathrm{~m}^{3} \cdot \mathrm{s}^{-1}$.

- for the second scenario the results show that there is a difference between the simulated and the observed for the Grarem station (Fig. 5A2) - avg observed $=5.33$ $\mathrm{m}^{3} \cdot \mathrm{s}^{-1}$, avg simulated $=4.88 \mathrm{~m}^{3} \cdot \mathrm{s}^{-1}$, max observed $=$ $207.33 \mathrm{~m}^{3} \cdot \mathrm{s}^{-1}$, max simulated $=1192 \mathrm{~m}^{3} \cdot \mathrm{s}^{-1}$, Tassadane (Fig. 5B2) - avg observed $=3.28 \mathrm{~m}^{3} \cdot \mathrm{s}^{-1}$, avg simulated $=2.36 \mathrm{~m}^{3} \cdot \mathrm{s}^{-1}$, max observed $=250.71 \mathrm{~m}^{3} \cdot \mathrm{s}^{-1}$, max simulated $=478.40 \mathrm{~m}^{3} \cdot \mathrm{s}^{-1}$, Ain Smara (Fig. 5C2)- avg observed $=1.24 \mathrm{~m}^{3} \cdot \mathrm{s}^{-1}$, avg simulated $=1.16 \mathrm{~m}^{3} \cdot \mathrm{s}^{-1}, \max$ observed $=143.03 \mathrm{~m}^{3} \cdot \mathrm{s}^{-1}$, max simulated $=242.70 \mathrm{~m}^{3} \cdot \mathrm{s}^{-1}$.

The data obtained generally confirmed that our model requires a calibration on parameters that influence on surface runoff and groundwater [ZHANG et al. 2008].

\section{SENSITIVITY ANALYZES}

Sensitivity analysis is an approach that evaluates the impact of changing input parameters on the model results. In this study SWAT-CUP (Calibration Uncertainty Procedures) software is used utilizing the SUFI-2 algorithm (Sequential Uncertainty Fitting, ver. 2) [ABBASPOUR 2013]. In order to see the influence of surface runoff and groundwater parameters on the model results, 50 simulations performed for each hydrometric station.

\section{MODEL EVALUATION}

Both scenarios are evaluated using the Nash-Sutcliffe efficiency coefficient (NSE) [NASH, SUTCLIFFE 1970], and the determination coefficient $\left(R^{2}\right)$ [TARALD 1985],

It can be judged as unsatisfactory when NSE is less than 0.36 , or that model simulation is satisfactory if $0.36>$ NSE $>0.75$ (Tab. 7) [KRAUSE et al. 2005; MORIASI et al. 2007].

\section{CALIBRATION AND RESULT}

The calibration parameters of the model in the two scenarios represented in the Table 5.

To calibrate and validate our results, we divided the periods of each station to see the compatibility of the model: - for the Grarem station calibration over the period 01.01.1992-30.06.1996, and validation 01.07.199631.12.2000;

- for the Tassadane station calibration over the period 01.01.1981-31.12.1993, and validation 01.01.199431.12.2006;

- for the Ain Smara station calibration over the period 01.01.1985-30.06.1988, and validation 01.07.198831.12.1991.

The results are shown in the Tables 6, 7 and Figure 7. 


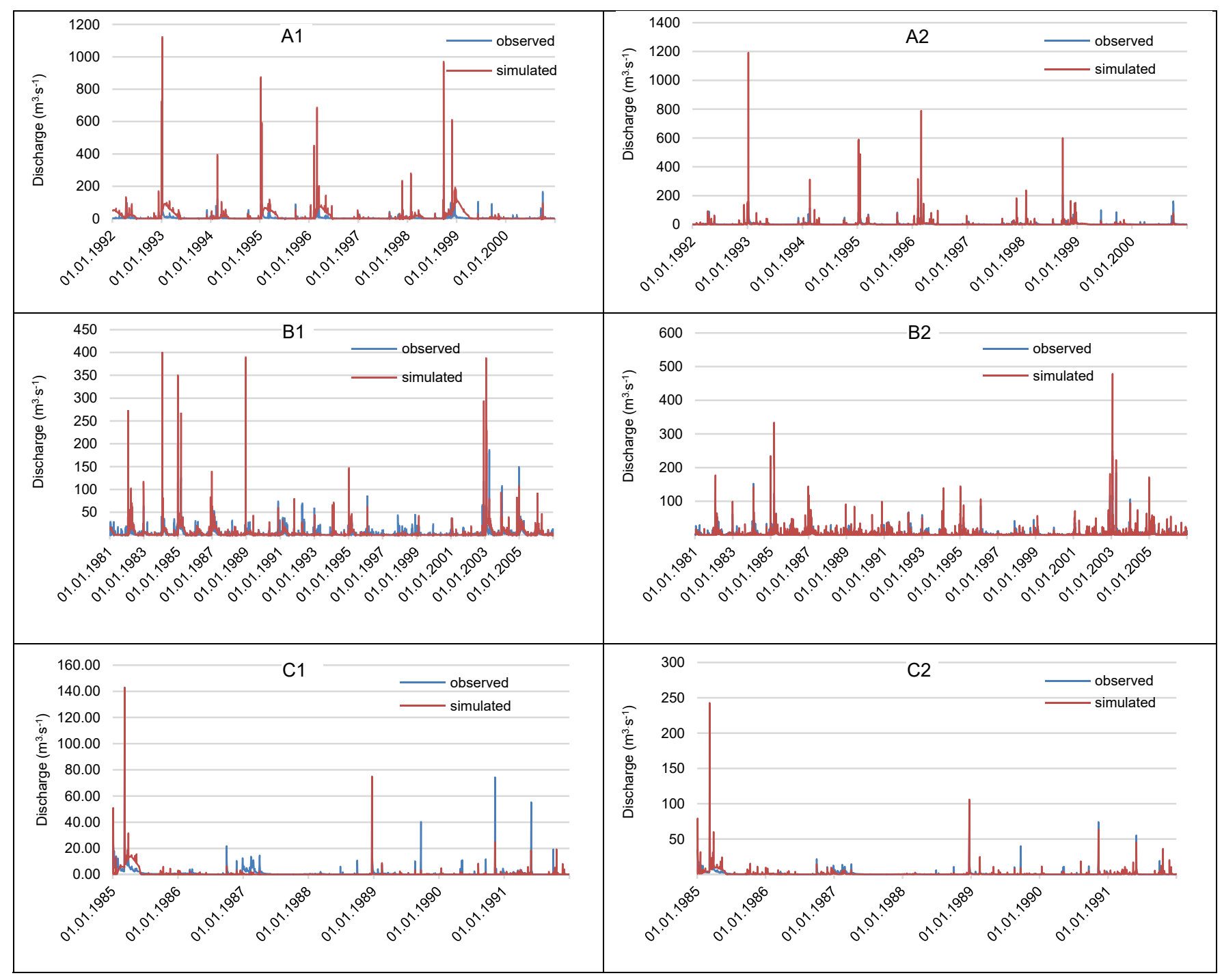

Fig. 5. Daily simulated and observed discharge $\left(\mathrm{m}^{3} \cdot \mathrm{s}^{-1}\right)$ in studied stations for both scenarios: A1) Grarem station, scenario 1;

A2) Grarem station, scenario 2; B1) Tassadane station, scenario 1; B1) Tassadane station, scenario 2, C1) Ain Smara station, scenario 1; C2) Ain Smara station, scenario 2; source: own study

Table 5. Calibrated parameter values with a ranking of the most sensitive parameters

\begin{tabular}{|c|c|c|c|c|c|c|c|}
\hline Parameter & Definition & $\begin{array}{c}\text { File } \\
\text { name }\end{array}$ & Initial value & $\begin{array}{c}\text { Calibration value } \\
\text { scenario } 1\end{array}$ & rank & $\begin{array}{c}\text { Calibration } \\
\text { value scenario } 2\end{array}$ & rank \\
\hline Cn2** & moisture condition curve number & $\mathrm{mgt}$ & $35-98$ & $-15 \%,-30 \%$ & 1 & $-15 \%,-45 \%$ & 4 \\
\hline SHALLST* & initial depth of shallow aquifer & \multirow{7}{*}{ gw } & $0-5000$ & 0.5 & 6 & $0.5-5000$ & 8 \\
\hline DEEPST* & initial depth of deep aquifer & & $0-10000$ & 1000 & 7 & $1000-10000$ & 9 \\
\hline GW_DELAY* & $\begin{array}{l}\text { groundwater delay: time required for water leaving the } \\
\text { bottom of the root zone to reach the shallow aquifer } \\
\text { (days) }\end{array}$ & & $0-500$ & 50 & 4 & $0.01-50$ & 7 \\
\hline ALPHA_BF* & $\begin{array}{l}\text { base flow alpha factor characterizes the groundwater } \\
\text { recession curve (days) }\end{array}$ & & $0-1$ & 0.5 & 2 & $0.059-1$ & 3 \\
\hline GWQMN* & $\begin{array}{l}\text { threshold depth of water in the shallow aquifer required } \\
\text { for return flow to occur ( } \mathrm{mm})\end{array}$ & & $0-5000$ & $5-5000$ & 3 & $5-5000$ & 1 \\
\hline GW_REVAP* & $\begin{array}{l}\text { groundwater "revap" coefficient: controls the amount } \\
\text { of water which evaporates from the shallow aquifer }\end{array}$ & & $0.02-0.2$ & 0.2 & 5 & $0.02-0.2$ & 6 \\
\hline REVAPMN* & $\begin{array}{l}\text { threshold depth of water in the shallow aquifer for } \\
\text { revap to occur }\end{array}$ & & $0-1000$ & 100 & 8 & $5-1000$ & 2 \\
\hline $\mathrm{AWC}^{* *}$ & soil available water storage capacity $\left(\mathrm{mm} \cdot \mathrm{mm}^{-1}\right)$ & sol & $0-1$ & $0 \%,+25 \%$ & 9 & $0 \%,+75 \%$ & 5 \\
\hline ESCO* & soil evaporation compensation coefficient & hru & $0-1$ & 1 & 10 & 1 & 10 \\
\hline
\end{tabular}

Explanations: rank $1=$ most sensitive; rank $10=$ less sensitive, $*$ replacement of values, $* *$ relative change. Source: own study. 
Table 6. Model performance

\begin{tabular}{|l|c|c|c|c|c|c|c|c|}
\hline \multirow{3}{*}{ Station } & \multicolumn{4}{|c|}{ Calibration } & \multicolumn{4}{c|}{ Validation } \\
\cline { 2 - 9 } & \multicolumn{2}{|c|}{ scenario 1 } & \multicolumn{2}{c|}{ scenario 2 } & \multicolumn{2}{c|}{ scenario 1 } & \multicolumn{2}{c|}{ scenario 2 } \\
\cline { 2 - 9 } & $R^{2}$ & $N S E$ & $R^{2}$ & $N S E$ & $R^{2}$ & $N S E$ & $R^{2}$ & $N S E$ \\
\hline Grarem & 0.45 & 0.69 & 0.60 & 0.55 & 0.47 & 0.64 & 0.56 & 0.66 \\
\hline Tassadane & 0.59 & 0.63 & 0.59 & 0.63 & 0.59 & 0.63 & 0.70 & 0.70 \\
\hline Ain Smara & 0.69 & 0.80 & 0.66 & 0.75 & 0.48 & 0.58 & 0.57 & 0.64 \\
\hline
\end{tabular}

Explanations: $R^{2}=$ determination coefficient, $N S E=$ Nash-Sutclife efficiency coefficient.

Source: own study.

Table 7. Model performance criteria

\begin{tabular}{|l|c|c|c|}
\hline \multicolumn{2}{|c|}{$N S E \in(-\infty ; 1.0]$} & \multicolumn{2}{c|}{$R^{2} \in[0 ; 1.0]$} \\
\hline Unsatisfactory & $N S E \leq 0.36$ & no correlation & $R^{2} \simeq 0$ \\
\hline Satisfactory & $0.36<N S E<0.50$ & acceptable & $R^{2}>0.5$ \\
\hline Very good & $0.75<N S E<1$ & good & $R^{2} \approx 1.0$ \\
\hline
\end{tabular}

Explanations as in Tab. 6 .

Source: own elaboration based on KRAUSE et al. [2005] and MORIASI et al. [2007].

\section{DISCUSSION}

The sensitivity analysis, which is based on the comparison of observed and simulated liquid flows, shows that the most sensitive parameters for the two scenarios are $\mathrm{Cn} 2$, GWQMN, ALPHA_BF, REVAPMN, GW_DELAY [ARNOLD et al. 2012] - Table 5. However, the sensitivity to each parameter is not the same in both scenarios. For instance, $\mathrm{Cn} 2$ is the most sensitive parameter in the first scenario, and in the validation period $0.65,0.73$. However, in the second scenario, parameter GWQMN (Tab. 5) is the most sensitive. These findings indicate that the data used are different. Note that the first scenario is very sensitive to land cover changes, but the second scenario is sensitive to groundwater parameters.

In a study of the R'dom watershed in North-West of Morocco the land cover parameter was the most sensitive parameter with the value of NSE, $R^{2}$ of the daily time steps in the calibration period is $0.58,0.79$ [BROUZIYNE et al. 2017]. In another study in the Tafna watershed in the simulation of the runoff the groundwater parameter have a big influence on the simulation result with value of NSE and $R^{2}$ of the flow simulation is NSE between 0.42 and 0.75 , and $R^{2}$ was in the interval from 0.25 to 0.84 [ZETTAM et al. 2017].

The water yields simulation results in each sub-basin, using the SWAT model after calibration, show that the simulation results of the second scenario are nearly similar to those provided by the National Hydric Resources Agency (Fr. Agence Nationale des Ressources Hydrique ANRH). based on the observations made between 1956 and 2002, with rainfall between 20 and $250 \mathrm{~mm} \cdot$ year $^{-1}$ [ANRH 2005a]. Note that the results obtained for the first scenario are between 11.67 and $39.26 \mathrm{~mm} \cdot$ year $^{-1}$, and those of the second scenario are between 35.50 and 100.50 mm·year ${ }^{-1}$ (Fig. 6).

In the first scenario, it is easy to notice that there is not a big difference between the simulated and observed concentration time profiles. In addition, the simulated discharge is greater than the observed one, particularly in the first and second events (Fig. 7C1).

On the other hand, in the second scenario, there is a difference between the simulated and observed concentration time profiles, and the peak simulated flow rates are larger than the observed ones (Fig. 7C1).

These findings are reflected in the validation period; indeed, in the first scenario, $R^{2}=0.48$ and NSE coefficient $=0.58$, and in the second scenario $R^{2}=0.57$ and NSE coefficient $=0.64$, which indicate that the 2 nd scenario gives better results and provides a good representation of the sub-basin that is controlled by the Station of Ain-Smara (Fig. 7C2-4).

Furthermore, the results of the second scenario turned out to be close to those provided by ANRH everywhere except in the extreme North and South of the basin. This is certainly due to interpolation errors because the northern part of the basin is a wetland [ANRH 2005c].

In general, the simulated discharge results suggest that the SWAT model allows reproducing successfully the hydrological process in all sub-basins controlled by the hydrometric stations at the daily time step.

However, regarding the Nash-Sutcliffe efficiency (NSE) coefficient, it is found that the results in the first scenario are between 0.63 and 0.8 , and the correlation coefficient $R^{2}$ is between 0.45 and 0.69 during the calibration period. During the validation period, the NSE gives values between 0.58 and 0.64 , with $R^{2}$ between 0.47 and 0.59 (Tab. 6). Moreover, the results of the second scenario using the NSE are within the interval from 0.55 to 0.75 and the values of $R^{2}$ range from 0.59 to 0.66 during the calibration period. As for the validation period, the NSE coefficient is between 0.64 and 0.70 and $R^{2}$ is between 0.56 and 0.70 , as reported in Table 6 .
A)

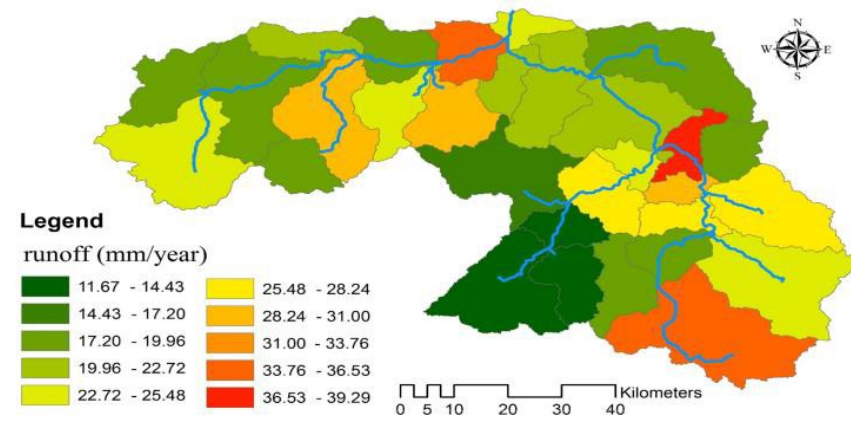

B)

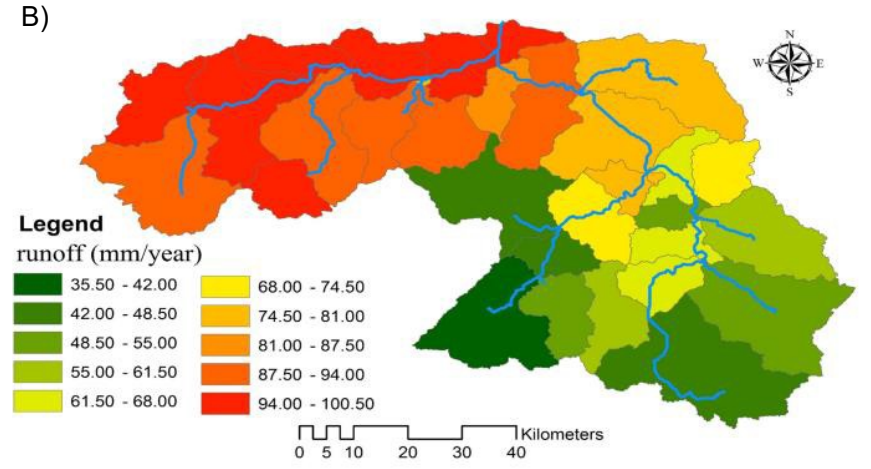

Fig. 6. Simulated runoff coming out of each sub-basin: A) first scenario, B) second scenario; source: own study 


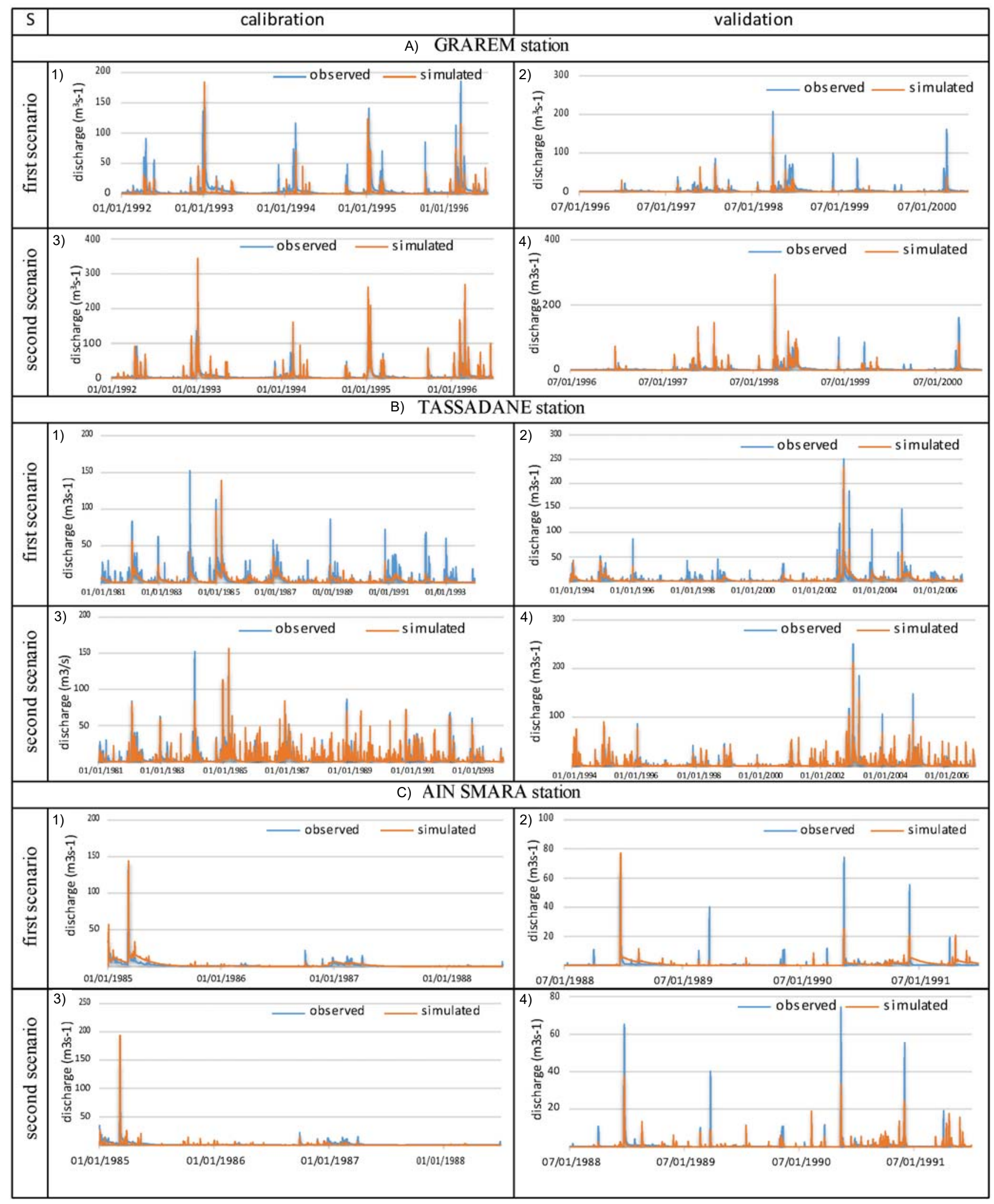

Fig. 7. Daily simulated and observed discharge $\left(\mathrm{m}^{3} \cdot \mathrm{s}^{-1}\right)$; A) Grarem station: 1) calibration scenario 1, 2) validation scenario 1 ,

3) calibration scenario 2,4) validation scenario 2; B) Tassadane station: 1) calibration scenario 1,2) validation scenario 1 ,

3) calibration scenario 2,4) validation scenario 2; C) Ain Smara station 1) calibration scenario 1,2) validation scenario 1,

3 ) calibration scenario 2, 4) validation scenario 2; source: own study 
Regarding the Grarem station, which controls an area of $4039 \mathrm{~km}^{2}$, five main events: i.e. 1) from 10.04 .1992 to 28.04.1992; 2) from 12.01 .1992 to 06.02 .1993 ; 3) from 17.02 .1994 to 12.03 .1994 ; 4) from 06.01 .1995 to 27.02.1995, and 5) from 05.02.1996 to 23.03.1996, are considered during the calibration period (Fig. 7A1-3).

It is easy to notice that, in the first scenario, the concentration times are different in all events; also, the simulated flow rates are lower than those observed, except for the second event (observed $136.67 \mathrm{~m}^{3} \cdot \mathrm{s}^{-1}$, simulated 184.2 $\mathrm{m}^{3} \cdot \mathrm{s}^{-1}$ (Fig. 7A1).

However, regarding the second scenario, the concentration time is almost the same in all the events, but the simulated peak flows in each event are lower than the ones observed (Fig. 7A3).

Considering the validation period, in the first scenario $R^{2}=0.47$ and NSE coefficient $=0.64$, but in the second scenario $R^{2}=0.56$ and NSE coefficient $=0.66$, which suggests that the input data and calibration parameters have an effect on flow in the second scenario; these findings allow for a better representation of the watershed that is controlled by the Grarem station (Fig. 7A2-4).

For the Tassadane station, which controls an area of $914.7 \mathrm{~km}^{2}, \mathrm{t} 12$ main events are considered over the calibration period (Fig. 7B1-3).

For the first scenario, one notices that the difference between the simulated and observed concentration time profiles is better than that given by the Grarem station, but the simulated peak flows in each event are less than the observed ones (Fig. 7B1).

On the other hand, in the second scenario, the concentration time in the different events is no better than that of the first scenario, and for the simulated peak flows, the same situation was more or less reproduced (Fig. 7B3).

During the validation period, the first scenario gives $R^{2}=0.59$ and NSE coefficient $=0.63$, and the second scenario $R^{2}=0.70, N S E=0.70$, which indicates that the data of the second scenario provide a better representation of the sub-basin controlled by the Tassadane station (Fig. 7B2-4).

For the station of Ain Smara, which controls an area of $1101 \mathrm{~km}^{2}$, one may distinguish 5 main events during the calibration period (Fig. 7C1-3).

On the basis of these results, one can notice that there is a difference between sub-basins vis-à-vis the quantity of water yields which can be influenced by different parameters, such as the groundwater parameters and land cover, and the types of soils.

For example, in the first scenario, the parameter that has the greatest influence on the simulation results is $\mathrm{Cn} 2$, which represents the number of curves in the SCS method. However, in the second scenario, the parameters that have the highest impact on the results are the groundwater parameters (Tab. 5).

In general, in both scenarios, the applied model succeeded to reproduce the hydrological cycle and also gave good results; however, the second scenario helped to carry out the best simulation. This may be attributed to the types of data that allowed having a better representation of the watershed.

\section{CONCLUSIONS}

The Soil and Water Assessment Tool (SWAT) was used in the present work in order to develop a hydrological model of the watershed of Beni Haroun dam, using two scenarios with two types of data related to soil types and land use (the first from GlobCover with HWSD and the second using the maps extracted from remote sensing of LANDSAT 8 satellite imagery), with the same meteorological data.

The simulation results obtained after calibration of the model suggest that the second scenario gives a better representation of the watershed at the daily time step (the results obtained for the water yields simulation in the first scenario are between 11.67 and $39.26 \mathrm{~mm} \cdot \mathrm{year}^{-1}$, and those of the second scenario are between 35.50 and 100.50 $\mathrm{mm} \cdot \mathrm{year}^{-1}$ compare to the observations made by the ANRH is between 20 and $250 \mathrm{~mm} \cdot$ year $^{-1}$ ); in addition, the first scenario provides acceptable results that allow making a general assessment on the basin.

Moreover, different results are found in the sub-basins; this can clearly be seen in the calibration of each sub-basin.

Due to its importance, the watershed of Beni Haroun dam needs additional climate and gauging stations in order to better simulate, estimate and assess the hydrological situation.

More research is needed particularly with regard to the calibration process while using the solid flow observations. This will certainly provide the opportunity to develop better hydrological modelling; it will also help to focus on climate change research within the basin in order to determine the vulnerable points within the dam and therefore lengthen its lifespan.

\section{REFERENCES}

ABBASPOUR K.C. 2013. SWAT-CUP 2012. SWAT Calibration and Uncertainty Program - A User Manual.

ACHARYA T.D., YANG I. 2015. Exploring Landsat 8. International Journal of IT, Engineering and Applied Sciences Research. Vol. 4. No. 4 p. 4-10.

ANDERSON J.R. 1976. A land use and land cover classification system for use with remote sensor data. US Government Printing Office.

ANRH 2004. Carte du réseau hydroclimatologique et de surveillance de la qualité des eaux 1:500,000 [Map of the hydroclimatological network and water quality monitoring]. Alger. Agence Nationale Ressources Hydraulices.

ANRH 2005a. Cares des ecoulement moyens annuels sur le nord de l'algrie, 1:500 000 [Average annual discharge maps for northern Algeria, 1: 500,000]. Alger. Agence Nationale Ressources Hydraulices.

ANRH 2005b. Catrte des reseau hydroclimatologique et de la surveillance de la quakut2 des eaux 1:500 000 [Map of Hydroclimatological Network and Water Quality Monitoring 1: 500 000]. Alger. Agence Nationale Ressources Hydraulices.

ANRH 2005c. Situation des etides pedologiques et agropedologiques du nord de l'algerie (1963-2004), 1:500 000 [Situation of pedological and agro-pedological studies of northern Algeria (1963-2004), 1: 500 000]. Alger. Agence Nationale Ressources Hydraulices. 
ANRH 2008. Carte des précipitations moyennes annuelles de l'Algérie, 1:500 000 [Map of average annual rainfall of Algeria, 1: 500 000]. Alger. Agence Nationale Ressources Hydraulices.

ARMON R.H., HÄNNINEN O. 2016. Environmental indicators. Springer. ISBN 9402403825 pp. 1068.

Arnold J., KiniRy J., SRinivasan R., Williams J., Haney E., NeITSCH S. 2013. SWAT 2012 input/output documentation. Texas Water Resources Institute.

Arnold J.G., Moriasi D.N., Gassman P.W., Abbaspour K.C., White M.J., SRinivasan R., SANThi C., Harmel R., VAN Griensven A., VAN LIEW M.W. 2012. SWAT: Model use, calibration, and validation. Transactions of the ASABE. Vol. 55 p. 1491-1508.

ARnold J.G., SRinivasan R., Muttiah R.S., Williams J.R. 1998. Large area hydrologic modeling and assessment part I: model development. Journal of the American Water Resources Association. Vol. 34 p. 73-89.

AUBERT G. 1978. Méthodes d'analyses des sols [Methods of soil analysis]. $2^{\text {nd }}$ ed. Marseille. Centre régional de documentation pédagogique pp. 191.

Barsi J. A., Lee K., Kvaran G., Markham B.L., Pedelty J.A. 2014. The spectral response of the Landsat- 8 operational land imager. Remote Sensing. Vol. 6 p. 10232-10251. DOI $10.3390 /$ rs61010232.

Bates B.C., Kundzewicz Z.W., Wu S., Palutikof J.P. (eds.) 2008. Climate change and water. Technical Paper of the Intergovernmental Panel on Climate Change. Geneva. IPCC. ISBN 978-92-9169-123-4 pp. 210.

BATJES N. 2009. Harmonized soil profile data for applications at global and continental scales: updates to the WISE database. Soil Use and Management. Vol. 25 p. 124-127.

Bishop T., HorTa A., KarUnARATnE S. 2015. Validation of digital soil maps at different spatial supports. Geoderma. Vol. 241 p. 238-249.

BlanCo-CANQUi H., Lal R. 2010. Soil and water conservation. In: Principles of soil conservation and management. Dordrecht. Springer p. 1-19. DOI 10.1007/978-1-4020-8709-7_1.

Boettinger J., RAMSey R., Bodily J., Cole N., Kienast-Brown S., Nield S., SAunders A., Stum A. 2008. Landsat spectral data for digital soil mapping. In: Digital soil mapping with limited data. Eds. A.E. Hartemink, A. McBratney, M.L. Mendonça-Santos. Springer p. 193-202.

Boucefiane A., Meddi M., Laborde J.P., Eslamian S. 2014. Rainfall frequency analysis using extreme values distributions in the steppe region of Western Algeria. International Journal of Hydrology Science and Technology. Vol. 4 p. 348-367.

Brouziyne Y., Abouabdillah A., Bouabid R., Benaabidate L., OuESLATI O. 2017. SWAT manual calibration and parameters sensitivity analysis in a semi-arid watershed in north-western Morocco. Arabian Journal of Geosciences. Vol. 10, 427 p. 113. DOI 10.1007/s12517-017-3220-9.

CARTER M.R., GreGORICH E.G. 2008. Soil sampling and methods of analysis. CRC Press. ISBN 978-0-8493-3586-0 pp. 1264.

De Vente J., Poesen J. 2005. Predicting soil erosion and sediment yield at the basin scale: scale issues and semiquantitative models. Earth-Science Reviews. Vol. 71 p. 95125.

Douglas-Mankin K., Srinivasan R., Arnold J. 2010. Soil and Water Assessment Tool (SWAT) model: Current developments and applications. Transactions of the ASABE. Vol. 53 p. 1423-1431.

EL-SADEK A., IRVEM A. 2014. Evaluating the impact of land use uncertainty on the simulated streamflow and sediment yield of the Seyhan River basin using the SWAT model. Turkish Journal of Agriculture and Forestry. Vol. 38 p. 515-530.
Gassman P.W., Sadeghi A.M., Srinivasan R. 2014. Applications of the SWAT model special section: overview and insights. Journal of Environmental Quality. Vol. 43 p. 1-8.

GIRI C.P. 2012. Remote sensing of land use and land cover: Principles and applications. CRC Press. ISBN 1420070746 pp. 477.

Hartemink A.E., Mcbratney A., Mendonça-SAntos M.D.L. 2008. Digital soil mapping with limited data. Springer Science, Business Media pp. XXIV + 439. DOI 10.1007/978-14020-8592-5.

Krause P., Boyle D., BäSe F. 2005. Comparison of different efficiency criteria for hydrological model assessment. Advances in Geosciences. Vol. 5 p. 89-97.

LCPC 1987. Analyse granulométrique par sédimentométrie. Méthode d'essai [Particle size analysis by sedimentometry. Test method]. LPC. No 18. Paris. Ministère de l'équipement, du logement, de l'aménagement du territoire et des transports. Laboratoire central des ponts et chaussées pp. 34.

LEFLAIVE X. 2012. Water outlook to 2050: The OECD calls for early and strategic action. Global Water Forum. Discussion Paper 1219. Canberra, Australia 21.05.2012 p. 1-6.

Ministère du Développement Durable, de L'environnement et des Parcs du Québec 2010. Guide d'échantillonnage à des fins d'analyses environnementales. Cahier 5 - Échantillonnage des sols [Sampling guide for environmental analyzes. Book 5 - Soil sampling] [online]. Québec. Centre d'expertise en analyse environnementale du Québec. Édition courante. ISBN 978-2-550-57649-5 pp. 57. [Access 15.10.2018]. Available at: http://www.ceaeq.gouv.qc.ca/documents/publications/ echantillonnage/solsC5.pdf

Moriasi D.N., ARnold J.G., Van Liew M.W., Bingner R.L., HARMEL R.D., VEITH T.L. 2007. Model evaluation guidelines for systematic quantification of accuracy in watershed simulations. Transactions of the ASABE. Vol. 50 p. 885-900. DOI 10.13031/2013.23153.

Mwaniki M.W., Moeller M.S., Schellmann G. 2015. A comparison of Landsat $8(\mathrm{OLI})$ and Landsat $7(\mathrm{ETM}+)$ in mapping geology and visualising lineaments: A case study of central region Kenya. The International Archives of Photogrammetry, Remote Sensing and Spatial Information Sciences. Vol. 40 p. 897-903. DOI 10.5194/isprsarchives-XL-7-W3897-2015.

NASH J.E., SutClifFE J.V. 1970. River flow forecasting through conceptual models. Part 1. A discussion of principles. Journal of Hydrology. Vol. 10 p. 282-290.

Neitsch S.L., ARnold J.G., KiniRy J.R., Williams J.R. 2011. Soil and water assessment tool. Theoretical documentation. Version 2009. Texas Water Resources Institute. Technical report. No. 406 pp. 618.

NF P94-056 1996. Sols : reconnaissance et essais - Analyse granulométrique - Méthode par tamisage à sec après lavage [Soil: investigation and testing - Granulometric analysis Dry sieving method after washing].

Parece T., CAmpbell J., MCGeE J. 2014. Remote sensing in an ArcMap environment. VirginiaView pp. 255.

Rakshit A., ABhilash P.C., Singh H.B., GHOSh S. (eds.) 2017. Adaptive soil management: From theory to practices. Springer. ISBN 9789811036378 pp. 571.

SAXTON K.E., RAWLS W.J. 2006. Soil water characteristic estimates by texture and organic matter for hydrologic solutions. Soil Science Society of America Journal. Vol. 70 p. 1569 1578.

SCHMIDT J. (ed.) 2013. Soil erosion: Application of physically based models. Springer Science, Business Media. ISBN 3662042959 pp. 318.

Sergio D.Z. 2012. Modelagem hidrológica da Bacia do Rio $\mathrm{Cu}-$ batão do Sul com modelo SWAT [Hydrological modeling of 
the Cubatão do Sul River Basin with SWAT model] [online]. Trabalho de Conclusão de Curso. Florianopolis. Universidade Federal de Santa Catarina pp. 120. [Access 15.10.2018]. Available at: https://repositorio.ufsc.br/bitstream/handle/ 123456789/125090/TCC2_Djesser_Zechner_Sergio_A5 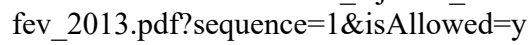

SOUKEHAL B., CHERRAD S.E. 2011. Les ressources en eau dans la wilaya de mila: mobilisation, consommation et comportement de menages [Water resources in the wilaya of mila: mobilization, consumption and behavior of households]. Sciences and Technologie. D Sciences de la terre. No. 34 p. 19-25.

TARALD O.K. 1985. Cautionary note about R2. The American Statistician. Vol. 39 p. 279-285.

Tuppad P., Douglas-Mankin K., Lee T., Srinivasan R., ARNOLD J. 2011. Soil and Water Assessment Tool (SWAT) hydrologic/water quality model: Extended capability and wider adoption. Transactions of the ASABE. Vol. 54 p. 1677-1684. DOI 10.13031/2013.39856.

VAYSSE K., LAGACHERIE P. 2015. Evaluating digital soil mapping approaches for mapping GlobalSoilMap soil properties from legacy data in Languedoc-Roussillon (France). Geoderma Regional. Vol. 4 p. 20-30. DOI 10.1016/j.geodrs.2014.11.003.

Williams J.R. 1995. The EPIC model. In: Computer models of watershed hydrology. Ed. V.P. Singh. Chapt. 25. Highlands Ranch, Colo. Water Resources Publications p. 909-1000.

Zettam A., Taleb A., Sauvage S., Boithias L., Belaidi N., SÁNCHEZ-PÉREZ J. 2017. Modelling hydrology and sediment transport in a semi-arid and anthropized catchment using the SWAT model: The case of the Tafna river (northwest Algeria). Water. Vol. 9. Iss. 3, 216 p. 1-18. DOI 10.3390/ w9030216.

Zhang X.-S., SRINIVASAn R., VAN LIEW M. 2008. Multi-site calibration of the SWAT model for hydrologic modeling. Transactions of the ASABE. Vol. 51 p. 2039-2049. DOI $10.13031 / 2013.25407$.

Zhang X., IZaurralde R., Zong Z., ZhaO K., Thomson A. 2012. Evaluating the efficiency of a multi-core aware multiobjective optimization tool for calibrating the SWAT model. Transactions of the ASABE. Vol. 55 p. 1723-1731. DOI $10.13031 / 2013.42363$.

\section{Zakaria KATEB, Hamid BOUCHELKIA, Abdelhalim BENMANSOUR, Fadila BELARBI}

\section{Modelowanie hydrologiczne za pomocą modelu SWAT na podstawie dwóch typów danych dotyczących zlewni zbiornika zaporowego Beni Haroun w Algierii}

\section{STRESZCZENIE}

Beni Haroun jest największym zbiornikiem zaporowym Algierii zasilającym w wodę siedem prowincji we wschodniej części kraju. Podjęcie badań jego zlewni oraz wszystkich czynników, które wpływają na dostawę wody i zawiesiny do zbiornika, okazało się pilne ze względu na regionalne znaczenie zbiornika. Model SWAT (Soil and Water Assessment Tool) wykorzystano do ilościowego ujęcia natężenia przepływu wody i identyfikacji wrażliwych elementów systemu $\mathrm{z}$ użyciem dwóch scenariuszy. W pierwszym wykorzystano dane światowe, w drugim dane z teledetekcji i cyfrowych map glebowych celem ustalenia najbardziej odpowiednich danych do osiągnięcia najlepszych rezultatów. Model SWAT można użyć do odtworzenia cyklu hydrologicznego na obszarze zlewni. Według pierwszego scenariusza podczas kalibracji $R^{2}$ wynosił od 0,45 do 0,69, a współczynnik efektywności Nasha-Sutcliffa (NSE) mieścił się w przedziale od 0,63 do 0,80. Podczas walidacji $R^{2}$ zmieniał się od 0,47 do 0,59 , a współczynnik NSE od 0,58 do 0,64. Według drugiego scenariusza podczas kalibracji $R^{2}$ wynosił od 0,60 do 0,66 , a współczynnik $N S E$ od 0,55 do 0,75 . Podczas walidacji współczynniki mieściły się odpowiednio w granicach od 0,56 do 0,70 i od 0,64 do 0,70. Wyniki wskazują, że dane pozyskane z teledetekcji i cyfrowych map glebowych stanowią lepszą reprezentację zlewni i umożliwiają usprawnienie modelowania hydrologicznego.

Słowa kluczowe: Beni Haroun, kalibracja, model SWAT, natężenie przeptywu wody, zlewnia 